medRxiv preprint doi: https://doi.org/10.1101/2021.12.30.21266217; this version posted January 1 , 2022. The copyright holder for this preprint (which was not certified by peer review) is the author/funder, who has granted medRxiv a license to display the preprint in It is made available under a CC-BY-NC-ND 4.0 International license .

\title{
Increased Risk of Poor Clinical Outcome in COVID-19 Patients with Diabetes Mellitus and in- hospital Mortality Predictors: A Retrospective Cohort from a Tertiary Hospital in Indonesia
}

Md Ikhsan Mokoagow ${ }^{1,2}$, Dante Saksono Harbuwono, ${ }^{3}$ Ida Ayu Kshanti, ${ }^{1}$ C Martin Rumende ${ }^{4}$, Imam Subekti ${ }^{3}$, Kuntjoro Harimurti ${ }^{4}$, Khie Chen Lie $^{2}$, Hamzah Shatri ${ }^{2,4}$

${ }^{1}$ Division of Endocrinology, Metabolism, and Diabetes, Department of Internal Medicine, Fatmawati General Hospital, Jakarta, Indonesia

${ }^{2}$ Departement of Internal Medicine, Faculty of Medicine, Universitas Indonesia

${ }^{3}$ Division of Endocrinology and Metabolism, Department of Internal Medicine, Dr. Cipto

Mangunkusumo National Referral Hospital, Faculty of Medicine Universitas Indonesia

${ }^{4}$ Clinical Epidemiology Unit, Department of Internal Medicine, Dr. Cipto Mangunkusumo National Referral Hospital, Faculty of Medicine Universitas Indonesia

\begin{abstract}
Aim: To determine association between diabetes in confirmed cases of COVID-19 and intensive care admission and in-hospital mortality, evaluate several laboratory parameters as mortality predictor, and develop predictors of in-hospital mortality among diabetics with COVID-19.

Methods: This retrospective cohort recruited all cases of COVID-19 hospitalized in Fatmawati General Hospital during March to October 2020. Inclusion criteria was RT-PCR confirmed cases of COVID-19 who aged 18 years and older while exclusion criteria were incomplete medical record or cannot be found and pregnant women.

Results: We enrolled 506 participants to this study with median age of 51 years (IQR:22), female (56.32\%), and diabetes (28.46\%). Diabetes increased intensive care admission (adjusted OR:6.07;95\%Cl:3.52-10,43) and in-hospital mortality (adjusted OR:50;95\%Cl:1.61-3.89). In predicting in-hospital mortality, ferritin and lactate dehydrogenase offered an acceptable discrimination, AUC:0.71 (95\%Cl: 0.62-0.79) and AUC:0.70 (95\% Cl: 0.61-0.78), respectively. The optimal cut-off of predicting mortality for ferritin was $786 \mathrm{~g} / \mathrm{mL}$ and for LDH was $514.94 \mathrm{u} / \mathrm{L}$. Factors include age above 70 years old, RBGs level on admission above $250 \mathrm{mg} / \mathrm{dL}$ or below $140 \mathrm{mg} / \mathrm{dL}$, ferritin level above 786 $\mathrm{ng} / \mathrm{mL}$, and presence of ARDS increased the odds of mortality among individuals with diabetes.

Conclusions: Diabetes increases risk of intensive care admission and in hospital mortality in COVID-19. Multivariate analysis showed that older age, RBG on admission, high ferritin level, presence of ARDS increased the odds of mortality among individuals with diabetes.
\end{abstract}

Keywords: Diabetes mellitus, COVID-19, intensive care, mortality, predictor. 
medRxiv preprint doi: https://doi.org/10.1101/2021.12.30.21266217; this version posted January 1 , 2022. The copyright holder for this preprint (which was not certified by peer review) is the author/funder, who has granted medRxiv a license to display the preprint in It is made available under a CC-BY-NC-ND 4.0 International license .

\section{INTRODUCTION}

Coronavirus Disease-2019 (COVID-19) first identified in Wuhan China and subsequently spread worldwide hence emerged as global health problem. Currently its case fatality rate in Indonesia exceeded the global rate. ${ }^{1}$ Presence of comorbidity contribute to poor clinical outcome. ${ }^{2}$ COVID-19 patients with diabetes are at risk of developing poor outcome during hospitalization. ${ }^{3,4}$ Our preliminary data in early pandemic documented half of individuals with diabetes admitted to our hospital due to COVID-19 were in critical diseases with a mortality rate of over $60 \%$ in this group. ${ }^{5}$ Identifying individuals with diabetes who are at higher risk of having clinical deterioration is of clinical importance.

Laboratory findings as predictors for poor outcome in COVID-19 has been extensively studied. Parameters such as C-reactive protein, lactate dehydrogenase, ferritin, D-dimer, neutrophils to lymphocyte ratio and monocyte to lymphocyte ratio have been associated with poor clinical outcome in COVID-19. ${ }^{6-17}$

It is conceivable that diabetes may contribute to poor clinical outcome and laboratory findings may predict in hospital mortality. Nevertheless, studies relating these occurrence remains limited. We sought to determine the association between diabetes in confirmed cases of COVID-19 and intensive care admission and in-hospital mortality, evaluate several laboratory parameters as mortality predictor, and develop predictors of in-hospital mortality among diabetics with COVID-19.

\section{METHODS}

\subsection{Study design and participant}

This is a single-centre, retrospective cohort study conducted in Fatmawati General Hospital from March to October 2020. Fatmawati General Hospital is a tertiary hospital located in South Jakarta. This hospital served as a referral hospital for severe COVID-19 for three consecutive cities, including South Jakarta, Depok, and South Tangerang cities (total population of 6,343,000). A total of 1,872 COVID-19 patients (confirmed and probable) were admitted during the study period. We included all COVID-19 confirmed individuals diagnosed based on RT-PCR test of nasal or oral-pharyngeal swab specimen, aged above 18 years or older, and at least had one measurement of random blood glucose test during admission. Individuals who were pregnant and data for the outcome cannot be achieved excluded from this study.

\subsection{Outcomes}

We reviewed demographical data, comorbidities, and laboratory findings based on patients' medical charts. Diabetes was determined based on the patient's medical history and laboratory parameters, including $\mathrm{HbA1C} \geq 6.5$ or fasting blood glucose $\geq 126 \mathrm{mg} / \mathrm{dL}$ or random blood glucose $\geq 200 \mathrm{mg} / \mathrm{dL}$ in two consecutive measurements. Comorbidity was determined based on the patient's medical history and categorized into without comorbidity, present of 1 comorbidity, and present two or more comorbidity. Laboratory findings consisted of random blood glucose test (RBGs), C-reactive protein (CRP), Ferritin, D-dimer, lactate dehydrogenase (LDH), Neutrophile to lymphocyte ratio (NLR), and monocyte to lymphocyte ratio (MLR), all obtained at the time of admission. The disease severity was categorized based on WHO COVID-19 severity.1

Acute respiratory distress syndrome (ARDS) was determined based on oxygen saturation measured by pulse oximetry/ FiO2 ratio $<315$ at the time of admission. We assessed the incidence of intensive care treatment, and mortality of COVID-19 patients with or without prior diabetes condition treated in our hospital. 
medRxiv preprint doi: https://doi.org/10.1101/2021.12.30.21266217; this version posted January 1, 2022. The copyright holder for this preprint (which was not certified by peer review) is the author/funder, who has granted medRxiv a license to display the preprint in perpetuity.

It is made available under a CC-BY-NC-ND 4.0 International license .

\subsection{Statistical analysis}

Numeric data were presented as a median and inter-quartile range (IQR) or mean and standard deviation (SD) as determined by the Shapiro-Wilk test. Categorical data were presented as frequency and percent. Laboratory data cut-off was obtained based on previously published research for predicting critical conditions in COVID-19 patients. The cut-off for laboratory findings were RBG 180 $\mathrm{mg} / \mathrm{dL}$, CRP $5.213 \mathrm{mg} / \mathrm{dL}$, Ferritin $304.3 \mathrm{ng} / \mathrm{mL}$, d-dimer 2,010 ng/mL, LDH $353.5 \mathrm{u} / \mathrm{L}$, NLR 8.085, MLR 0.364 respectively for intensive care outcome, and RBG $180 \mathrm{mg} / \mathrm{dL}$, CRP $2.587 \mathrm{mg} / \mathrm{dL}$, Ferritin 163.5 $\mathrm{ng} / \mathrm{mL}$, d-dimer $565 \mathrm{ng} / \mathrm{mL}$, LDH $277 \mathrm{u} / \mathrm{L}$, NLR 5.87, MLR 0.30 respectively for mortality outcome. Bivariate analysis using the chi-square test and multivariate logistics regression was performed to obtain crude and adjusted odds ratios. We assessed the association between diabetes and outcome using causative models. Nearly all study variables were assessed for their relationship with the outcomes. Backward selection for selecting covariates as confounding factors was used. Suppose the exclusion of covariate changes the OR crude of diabetes by more than $10 \%$ than the covariates is considered a potential confounder. If there is a clinically meaningful relationship, the potential confounders are regarded as confounders, and adjusted ORs of association between diabetes and outcomes were obtained. We measured the performance of laboratory findings by measuring the area under curve, sensitivity, and specificity. The optimal cut-off value is measured by determining the closest distance between the point $(0,1)$ and the point on the ROC curve (d) and determining the farthest vertical distance between the line of equality and the point on the ROC curve (Youden index). All the analysis was performed using STATA Version 12 . The study was reviewed and approved by the Research Ethic Committee of Fatmawati General Hospital (27/KEP/XII/2020).

\section{RESULTS}

\subsection{Patients characteristics}

During the study period from 11 March to 31 November 2020, a total of 616 confirmed COVID-19 patients were admitted to our hospital. Of all of them, only 600 complete medical records can be obtained. We excluded children (27 persons), pregnant women (65 persons), and those who never had blood glucose measurements during admission (6 persons). Therefore, a total of 506 participants were included in this study (Figure 1)

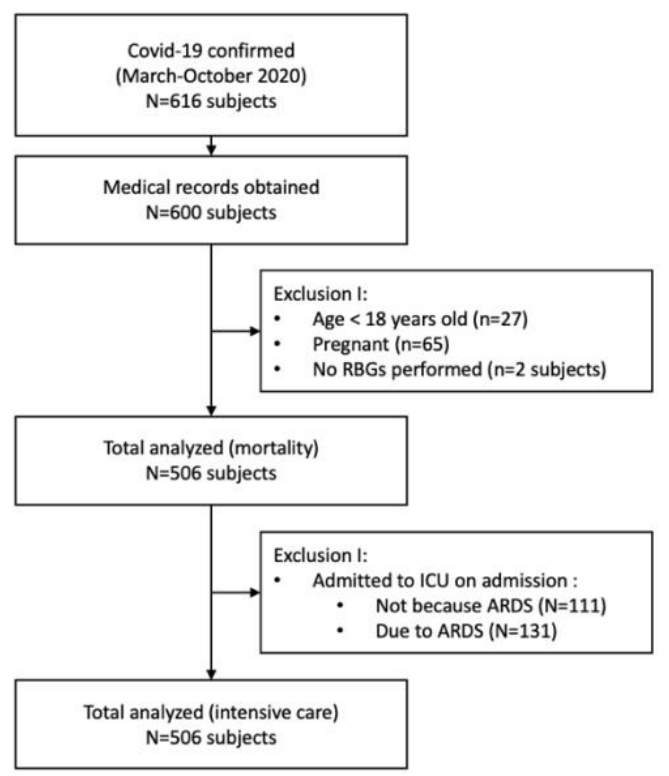

Figure 1. Flow Diagram 
medRxiv preprint doi: https://doi.org/10.1101/2021.12.30.21266217; this version posted January 1, 2022. The copyright holder for this preprint (which was not certified by peer review) is the author/funder, who has granted medRxiv a license to display the preprint in

It is made available under a CC-BY-NC-ND 4.0 International license .

The characteristic of the participants is presented in Table 1. Diabetes was found in $28.46 \%$ of individuals. Most of the subjects in this study were below 60 years old, with a median (IQR) age 51 (22) years old. Females are more prevalent compare to males ( 56.32 vs. $43.68 \%$ ). Despite diabetes, the most common comorbidity found in this study was hypertension $(30.80 \%)$ and chronic kidney disease (24.20\%).). The proportion of severity levels among subjects at the admission time was as follows; mild $11.07 \%$, moderate $34.39 \%$, severe $8.89 \%$, and critical $45.85 \%$ (ARDS $44.66 \%$, sepsis $1.19 \%$, septic shock $6.72 \%$ ). The mean hospital duration in this study was 13 (12 days).

Table 1. Characteristics of subjects

\begin{tabular}{|c|c|c|c|}
\hline \multirow[t]{3}{*}{ Variable } & \multirow[t]{3}{*}{ Total } & \multicolumn{2}{|c|}{ Diabetes } \\
\hline & & Yes & No \\
\hline & & $144(28,46)$ & $362(71,54)$ \\
\hline Age, years old - Median (IQR) & $51(22)$ & $57(15)$ & $48,5(22)$ \\
\hline \multicolumn{4}{|l|}{ Age Category } \\
\hline$\geq 60$ years old & $143(28,26)$ & $60(41,67)$ & $83(22,93)$ \\
\hline$<60$ years old & $363(71,47)$ & $84(58,33)$ & $279(77,07)$ \\
\hline \multicolumn{4}{|l|}{ Sex } \\
\hline Male - n (\%) & $221(43,68)$ & $67(46,53)$ & $154(42,54)$ \\
\hline Female - n (\%) & $285(56,32)$ & $77(53,47)$ & $208(57,46)$ \\
\hline \multicolumn{4}{|l|}{ Comorbidity } \\
\hline Hypertension - n (\%) & $154(30,80)$ & $60(42,25)$ & $94(26,6)$ \\
\hline Heart disease $-\mathrm{n}(\%)$ & $57(11,40)$ & $22(15,49)$ & $35(9,78)$ \\
\hline $\begin{array}{l}\text { Chronic obstructive pulmonary } \\
\text { disease }-\mathrm{n}(\%)\end{array}$ & $23(4,60)$ & $6(4,23)$ & $17(4,75)$ \\
\hline Stroke - n (\%) & $21(4,20)$ & $5(3,52)$ & $16(4,47)$ \\
\hline Chronic kidney disease $-\mathrm{n}(\%)$ & $121(24,20)$ & $43(30,28)$ & $78(21,79)$ \\
\hline Liver Disease - n (\%) & $5(0,99)$ & $1(0,69)$ & $4(1,10)$ \\
\hline Other immunodeficiency - $\mathrm{n}(\%)$ & $19(3,80)$ & $8(5,64)$ & $11(3,08)$ \\
\hline \multicolumn{4}{|l|}{ Laboratory parameters } \\
\hline RBGs, mg/dL - median (IQR) & $109(54)$ & $139,5(122)$ & $105(41)$ \\
\hline CRP, mg/dL - median (IQR) & $4,5(10,9)$ & $6,5(13,5)$ & $3,97(9,2)$ \\
\hline Feritin, ng/mL - median (IQR) & 542.5 (1172) & $772,5(1235,52)$ & 474 (1043) \\
\hline D-dimer, ng/mL - median (IQR) & $1570(2260)$ & $2260(3315,8)$ & $1390(2390,42)$ \\
\hline LDH, u/L - median (IQR) & $485,49(322)$ & $523,5(378,5)$ & $477,14(306,99)$ \\
\hline NLR - median (IQR) & $6,42(5,41)$ & $6,38(5,45)$ & $6,51(5,45)$ \\
\hline MLR - median (IQR) & $0,49(0,34)$ & $0,45(0,272)$ & $0,5(0,363)$ \\
\hline Hospital duration, day - median (IQR) & $13(12)$ & $15(16)$ & $13(8)$ \\
\hline
\end{tabular}

\subsection{The association between diabetes and outcome}

Of all of the subjects included, 297 (58.70\%) subjects were admitted to the intensive care unit, while $140(27.67 \%)$ subjects were dead during admission. Among subjects with diabetes versus subjects without diabetes, a higher proportion was admitted to intensive care $(86.11 \%$ vs. $47.79 \%$, respectively $p<0.001$, supplementary 1$)$ and death $(45.14 \%$ vs. $20.72 \%$, respectively $p<0.001$, supplementary 2$)$.

In multivariate logistic regression analysis, diabetes was associated with increased odds of admitted on intensive care OR 6.07 (95\% Cl: 3.52-10.43) (fig.2), and death OR 2.50 (95\% Cl: 1.61-3.89) (fig.3) after adjustment with age, sex, comorbidity, random blood glucose levels, C-reactive protein, ferritin, d-dimer, lactate dehydrogenase levels, neutrophile and monocyte to lymphocyte ratio levels. 
medRxiv preprint doi: https://doi.org/10.1101/2021.12.30.21266217; this version posted January 1 , 2022. The copyright holder for this preprint (which was not certified by peer review) is the author/funder, who has granted medRxiv a license to display the preprint in It is made available under a CC-BY-NC-ND 4.0 International license .

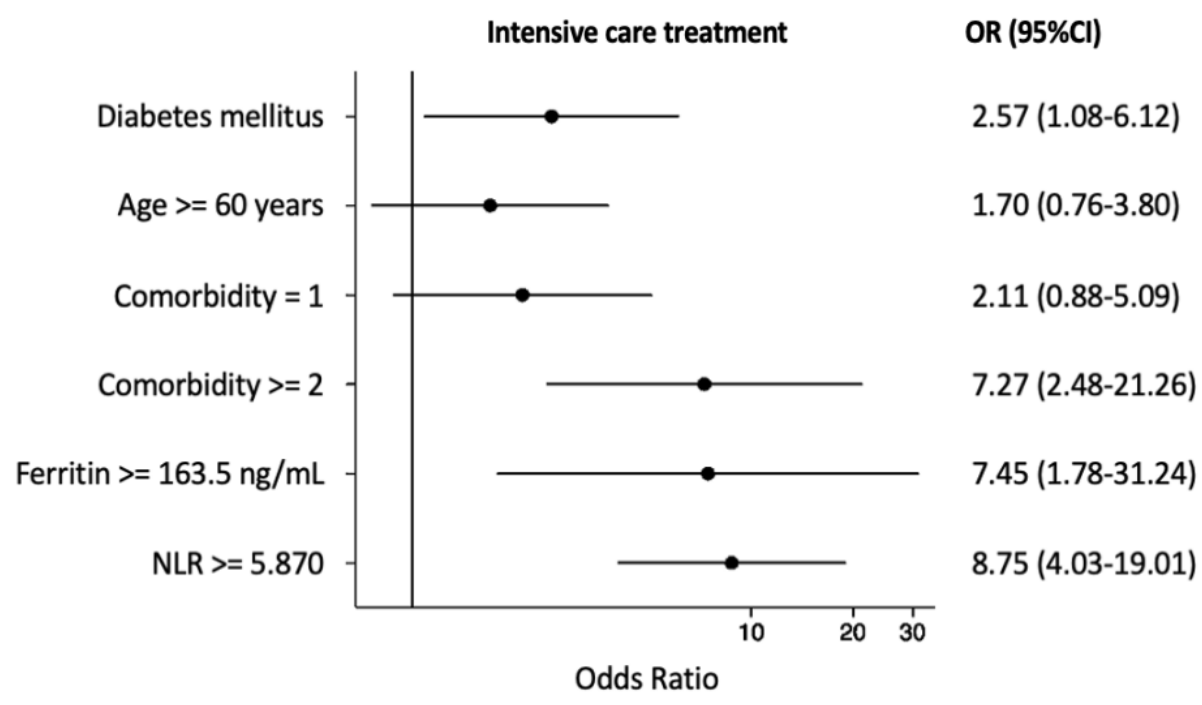

Figure 2. The Association between Diabetes and Intensive care treatment in COVID-19 patients

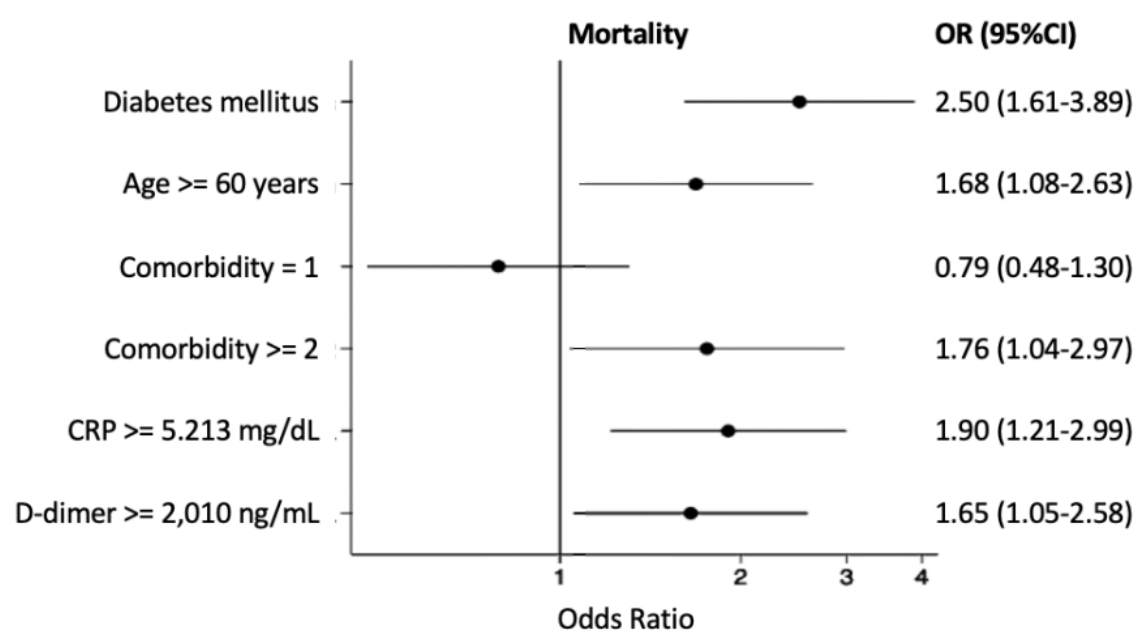

Figure 3. The Association between Diabetes and Mortality in COVID-19 patients

\subsection{Laboratory parameters as a mortality predictor in diabetes subjects}

The accuracy of laboratory parameters to predict mortality in diabetes subjects was shown based on the area under the curve (AUC) of each parameter. All of the laboratory parameters had AUC below 0.70 in predicting mortality of diabetes subjects except for ferritin (AUC: $0.71,95 \% \mathrm{Cl}: 0.62-0.79$ ) and LDH (AUC: $0.70,95 \% \mathrm{Cl}: 0.61-0.78$ ). The optimal cut-off for ferritin to predict mortality among subjects with diabetes was $786 \mathrm{ng} / \mathrm{mL}$ (sensitivity: 0.72 , specificity: 0.68 ) and the optimal cut off for LDH was $514.94 \mathrm{u} / \mathrm{L}$ (sensitivity: 0.71, specificity: 0.62) (Table 2).

Table 2. Laboratory parameters as a mortality predictor in COVID-19 with diabetes subjects

\begin{tabular}{lccccccccc}
\hline $\begin{array}{l}\text { Laboratory } \\
\text { parameter }\end{array}$ & AUC & $\begin{array}{c}\text { Cut- } \\
\text { off* }\end{array}$ & Spec* & Sens & Spec & PPV & NPV & LR+ & LR- \\
\hline CRP $(\mathrm{mg} / \mathrm{dL})$ & 0.650 & $\geq 5,213$ & 0,710 & 0,621 & 0,601 & 0,373 & 0,806 & 1,556 & 0,631 \\
LDH (u/L) & 0.675 & $\geq 353,5$ & 0,890 & 0,871 & 0,262 & 0,311 & 0,842 & 1,180 & 0,492 \\
$\begin{array}{l}\text { Ferritin (ng/mL) } \\
\text { d-dimer }\end{array}$ & 0.662 & $\geq 304,3$ & 0,706 & 0,779 & 0,352 & 0,315 & 0,806 & 1,202 & 0,628 \\
(ng/mL) & 0.645 & $\geq 2.010$ & 0,740 & 0,564 & 0,637 & 0,373 & 0,793 & 1,554 & 0,684 \\
\hline
\end{tabular}


medRxiv preprint doi: https://doi.org/10.1101/2021.12.30.21266217; this version posted January 1 , 2022. The copyright holder for this preprint (which was not certified by peer review) is the author/funder, who has granted medRxiv a license to display the preprint in It is made available under a CC-BY-NC-ND 4.0 International license .

\begin{tabular}{lccccccccc}
\hline NLR & 0.500 & $\geq 8,085$ & 0,848 & 0,221 & 0,762 & 0,263 & 0,719 & 0,929 & 1,022 \\
MLR & 0.503 & $\geq 0,364$ & 0,800 & 0,643 & 0,383 & 0,287 & 0,740 & 1,042 & 0,932 \\
RBGs (mg/dL) & 0.557 & $\geq 180$ & - & 0,271 & 0,861 & 0,427 & 0,755 & 1,950 & 0,847 \\
\hline
\end{tabular}

\subsection{Factors associated with mortality among diabetes subjects}

We explore factors affecting mortality in diabetes subjects. Based on bivariate analysis, some variables have a statistically significant association with mortality. They were random blood glucose levels, CRP, Ferritin, LDH, D-dimer, and ARDS (supplementary table 4). The multivariate analysis was performed. Based on multivariate analysis, it is seen that age above 70 years old, RBGs level above $250 \mathrm{mg} / \mathrm{dL}$ or below $140 \mathrm{mg} / \mathrm{dL}$, ferritin level above $786 \mathrm{ng} / \mathrm{mL}$, and presence of ARDS increased the odds of mortality among subjects with diabetes. Meanwhile, comorbidity, NLR above 4.69, and MLR above 0.8 are confounding factors that attenuate the other risks (Table 3 ).

Table 3. Risk Factor of mortality among COVID-19 with diabetes subjects.

\begin{tabular}{lcccc}
\hline Variable & Coefficient B & p-value & OR & 95\%Cl \\
\hline RBGs $\mathbf{~ m g / d L}$ & & & & \\
$\quad<140$ & 1,618 & 0,003 & 5,04 & $1,72-14,78$ \\
$\quad>250$ & 1,768 & 0,006 & 5,86 & $1,65-20,78$ \\
Age $\geq$ 70 years old & 0,283 & 0,033 & 1,33 & $1,02-1,72$ \\
NLR $\geq 4.69$ & 0,660 & 0,130 & 1,94 & $0,82-4,55$ \\
Ferritin $\geq 786 \mathbf{~ n g / m L}$ & 1,731 & 0,000 & 5,65 & $2,40-13,29$ \\
ARDS & 1,198 & 0,009 & 3,31 & $1,35-8,11$ \\
Constanta & $-3,498$ & 0,000 & 0,04 & $0,01-0,12$ \\
\hline
\end{tabular}

\section{DISCUSSION}

Our study is the first study in Indonesia that clinically analyzed the relationship between DM and COVID-19 outcomes. We found that the proportion of DM among COVID-19 confirmed patients admitted to our hospital was $28.5 \%$. Furthermore, DM increased the risk of having intensive care treatment by 6.07 , and death by 2.50 compared to those who did not have DM. This finding is consistence with other findings including a meta-analysis who included 76 studies, in which 10 studies (for severe outcome) and 8 studies (for mortality outcome) came from outside China. The risk of having severe condition increased by 2.02 (95 Cl: 1.44-2.84, $\mathrm{I}^{2}: 55 \%, \mathrm{P}<0.02$ ) and the risk of having mortality increased by 2.21 (95 Cl: $\left.1.83-2.66, \mathrm{I}^{2}: 50 \%, \mathrm{P}<0.01\right)$ in DM patients compared to those who did not had DM outside China. ${ }^{18}$ Other meta-analysis including in hospital adults' patients with COVID19 found the same. The risk of in hospital mortality increased by 2.39 (95 Cl: 1.65-3.46, I2: 62\%, $\mathrm{P}: 0.001) .{ }^{19}$ However, those meta-analysis failed to prove diabetes increased the risk of severe conditions. ${ }^{19}$ Other meta-analysis including three study analyzed intensive care treatment among COVID-19 also failed to prove diabetes increased the risk of having intensive care treatment. (OR: 1.47, $\left.95 \mathrm{Cl}: 0.38-5.67, \mathrm{I}^{2}: 63 \%, \mathrm{P}: 0.07\right){ }^{20}$

The results of previous meta-analysis studies are still conflicting and had high heterogeneity. In this study, the OR of the relationship between diabetes and intensive care was high, 6.07 . However, if we looked at the confidence interval in this relationship (3.52-10.43), the confidence interval is wide. Some reasons can explain this finding. First, besides clinical consideration, physicians' decision to admit subjects to an intensive care facility was affected by beds availability and family consent. Also, a small sample size might give a wide range of confidence intervals. From all 606 subjects admitted to our hospital, we could assess only 264 subjects (42.86\%) after the exclusion. Lastly, we used OR rather than Risk Ratio (RR) as an association measurement because we used logistic regression for 
medRxiv preprint doi: https://doi.org/10.1101/2021.12.30.21266217; this version posted January 1 , 2022. The copyright holder for this preprint (which was not certified by peer review) is the author/funder, who has granted medRxiv a license to display the preprint in

It is made available under a CC-BY-NC-ND 4.0 International license.

multivariate analysis. Therefore, we can assume that this relationship is not strong and is most likely affected by chance. Further research with clinically objective outcomes like ARDS, sepsis, or other critical conditions is recommended.

Besides of COVID-19, it is well known that subjects with diabetes are prone to have infections compared to non-diabetes subjects. There is also paucity evidence in epidemiological studies where DM patients had increased risk of having mortality by COVID-19. ${ }^{18-20}$ The potential mechanisms that could explain the high COVID-19 mortalities among DM subjects were impaired immune responses, glycemic instability, chronic subclinical inflammation, and the presence of associated comorbidities in diabetes subjects. ${ }^{21}$

Several abnormal immune system have been seen in diabetes subjects, those including higher affinity cellular binding for virus entry, inhibition of viral clearance, impaired T-cell function, lymphopenia, and exaggerated inflammatory response associated with an increased renin-angiotensin system (RAS) activation in several tissues. ${ }^{22,23}$ In addition, those conditions were worsened by chronic glycemic instability and association inflammation, which contribute to increased susceptibility to hyperinflammation and cytokine storm. ${ }^{23}$ This findings also supported our study in which high ferritin $(>786 \mathrm{ng} / \mathrm{mL}$ ) increased the risk of mortality.

To date, there is no available report regarding cut-off for laboratory findings in predicting mortality of COVID-19 patients with diabetes. In this study, among all the laboratory parameters, only ferritin shows good performance in predicting mortality. Ferritin gives an AUC score of 0.71 with an optimal cut-off at $786 \mathrm{ng} / \mathrm{mL}$, giving it a sensitivity of 0.72 and specificity of 0.68 . LDH seemed like a good predictor for mortality among subjects with diabetes. However, it failed to prove its association with mortality in multivariate analysis (supplementary table 4).

Many studies have been reported that ferritin is an independent factor of poor outcomes in COVID19 patients. ${ }^{24}$ Ferritin is an intracellular protein that can store iron and plays a critical role in inflammatory diseases. It is an acute-phase protein, which is elevated during inflammation or infection. The condition of "hyperferritinemia syndrome" is proved to be associated with highly active diseases, resulting in immune activation and coagulation disturbances. ${ }^{24}$ Among COVID-19 patients, subjects with diabetes conditions already had a higher baseline of ferritin. ${ }^{25,26}$ The out-of-control inflammatory state in diabetes subjects who are already on impaired immune response may cause widespread tissue damage and susceptibility to poor outcomes.

Subjects with diabetes also have a greater risk for poor glycemic control. Acute diabetes complications were likely to occur (Diabetic ketoacidosis, Hyperglycemia hyperosmolar syndrome, and hypoglycemia), which then inhibits the ability to mitigate sepsis and higher mortality rate due to the complication itself. ${ }^{23}$ Furthermore, the presence of associated morbidities and the use of agents that can modulate angiotensin-converting enzyme 2 (ACE2) expression have been put forth to explain the latter association. ${ }^{22}$ We demonstrated that age and random blood glucose levels on admission were the independent risk factors of mortality in COVID-19 subjects with diabetes. We found age is major role when diabetes subjects reached 70 years or older. Also, subjects with RBGs levels above 250 $\mathrm{mg} / \mathrm{dL}$ or below $140 \mathrm{mg} / \mathrm{dL}$ were found at increased risk of death.

Following our findings, a meta-analysis including 22 studies showed that individuals with a more severe diabetes condition have a poorer prognosis of COVID-19 compared to those with milder diabetes conditions. ${ }^{27}$ A Spanish COVID-19 registry found admission hyperglycemia (RBG $>180 \mathrm{mg} / \mathrm{dL}$ ) regardless of diabetes diagnosis was a strong predictor of all-cause mortality in non-critically hospitalized patients. ${ }^{28}$ Moreover, the chronic hyperglycemia condition also leads to increased fibrinogen amyloid changes, leading to hypercoagulability conditions. ${ }^{29}$ It is not surprising that hyperglycemia increased the risk of poor outcomes. Current evidence showed tight glucose control with insulin infusion in ICU had a lower risk of severe symptoms and mortality. It is also well known that hypoglycemia might produce the same effect as acute hyperglycemia. Nevertheless, glucose variability also induced cytokines release and worsened prognosis. Currently, the optimal cut-off for 
medRxiv preprint doi: https://doi.org/10.1101/2021.12.30.21266217; this version posted January 1 , 2022. The copyright holder for this preprint (which was not certified by peer review) is the author/funder, who has granted medRxiv a license to display the preprint in It is made available under a CC-BY-NC-ND 4.0 International license .

glycemic control among COVID-19 patients with hyperglycemia remains elusive. It is challenging to maintain normal glycemic in COVID-19 patients with glycemia, and it was even more complicated with the use of corticosteroid treatment. Therefore, increased attention is needed for blood glucose regulations in COVID-19 patients. Further research regarding optimal glucose target and evidence of treatment is needed.

This study has several limitations to be discussed. First, we cannot analyze the time relationship in this study. That is because we did not measure the diabetes duration. Second, diabetes is a heterogeneous population. We included all subjects with diabetes conditions, including type 1 diabetes, type 2 diabetes, newly diagnosed diabetes, controlled or uncontrolled diabetes, those who received insulin or oral diabetes medication. Therefore, there is no specificity in this study, nor we performed a subanalysis of which of these different factors might play a role in the outcome. Lastly, our study is conducted in a tertiary facility and one of the largest hospitals in Indonesia that the governmentappointed as an advanced referral hospital. About $45.85 \%$ of subjects in this study already came with critical conditions, and $8.89 \%$ were already in severe conditions. Therefore, readers should be careful in generalizing our results.

In accordance with our findings, a meta-analysis including 22 studies showed individuals with a more severe diabetes condition have a poorer prognosis of COVID-19 compared to those with milder diabetes conditions. ${ }^{27}$ A Spanish COVID-19 registry found admission hyperglycemia (RBG > $180 \mathrm{mg} / \mathrm{dL}$ ) regardless of diabetes diagnosis was a strong predictor of all-cause mortality in non-critically hospitalized patients. ${ }^{28}$ Moreover, the chronic hyperglycemia condition also leads to increased fibrinogen amyloid changes, leading to hypercoagulability conditions. ${ }^{29}$ It is not surprising that hyperglycemia increased the risk of poor outcome. ${ }^{30}$ Also, hypoglycemia might produce the same effect as acute hyperglycemia. The optimal cut-off for COVID-19 patients with hyperglycemia treatment remains elusive. Current evidence showed tight glucose control with insulin infusion in ICU had a lower risk of severe symptoms and mortality. ${ }^{31}$ But glucose variability also induced cytokines release and worsen prognosis. ${ }^{31}$ It is challenging to maintain normal glycemic in COVID-19 patients with glycemia and it was even harder with the use of corticosteroid treatment. Increased attention is needed for blood glucose regulations in COVID-19 patients. Further research regarding optimal glucose target and evidence of treatment is needed.

This study has several limitations to be discussed. First, we cannot analyze the time relationship in this study. That is because we did not measure the diabetes duration. Second, basically diabetes is heterogenous population, we included all subjects with diabetes conditions, including type 1 diabetes, type 2 diabetes, newly diagnosed diabetes, controlled or uncontrolled diabetes, those who received insulin or oral diabetes medication. Therefore, there is no specificity in this study, nor we performed a sub-analysis which of these different factors might play role in the outcome. Lastly, our study is conducted in a tertiary facility and one of the largest hospitals in Indonesia that the governmentappointed as an advanced referral hospital. About $45.85 \%$ of subjects in this study already came with critical conditions, and $8.89 \%$ were already in severe conditions. Therefore, readers should be careful in generalizing our results.

\section{CONCLUSION}

The increased risk of intensive care and mortality in people with diabetes mellitus who experience COVID-19 requires special attention from various stakeholders, including clinicians, hospitals, the government, and the community. In addition, suitable clinical and laboratory monitoring protocols are needed to anticipate early clinical deterioration.

\section{FUNDING None}


medRxiv preprint doi: https://doi.org/10.1101/2021.12.30.21266217; this version posted January 1 , 2022. The copyright holder for this preprint (which was not certified by peer review) is the author/funder, who has granted medRxiv a license to display the preprint in

It is made available under a CC-BY-NC-ND 4.0 International license .

\section{CONFLICTS OF INTEREST None}

\section{ACKNOWLEDGEMENTS}

The authors would like to acknowledge COVID-19 Management Tasks Force, Fatmawati General Hospital for their tremendous endeavour during the pandemic.

\section{REFERENCE}

1. WHO. COVID-19 Weekly Epidemiological Update. 2020. available from: https://www.who.int/docs/default-source/coronaviruse/situation-reports/20201020weekly-epi-update-10.pdf

2. Yang J, Zheng Y, Gou X, et al. Prevalence of comorbidities and its effects in patients infected with SARS-CoV-2: a systematic review and meta-analysis. Int J Infect Dis. May 2020;94:91-95.

3. Li B, Yang J, Zhao F, et al. Prevalence and impact of cardiovascular metabolic diseases on COVID-19 in China. Clin Res Cardiol. May 2020;109(5):531-538.

4. Roncon L, Zuin M, Rigatelli G, Zuliani G. Diabetic patients with COVID-19 infection are at higher risk of ICU admission and poor short-term outcome. J Clin Virol. Jun 2020;127:104354.

5. Kshanti IA, Aji G, Epriliawati M, et al. Clinical presentation and outcome of COVID-19 infection in Type 2 Diabetes Mellitus: a preliminary data from a tertiary hospital in Jakarta during the early days of the pandemic. Bali Medical Journal. 2020;9(3).

6. Velavan TP, Meyer CG. Mild versus severe COVID-19: Laboratory markers. Int J Infect Dis. Jun 2020;95:304-307.

7. Huang I, Pranata R, Lim MA, Oehadian A, Alisjahbana B. C-reactive protein, procalcitonin, Ddimer, and ferritin in severe coronavirus disease-2019: a meta-analysis. Ther Adv Respir Dis. Jan-Dec 2020;14:1753466620937175.

8. Bastug A, Bodur H, Erdogan S, et al. Clinical and laboratory features of COVID-19: Predictors of severe prognosis. Int Immunopharmacol. Nov 2020;88:106950.

9. Soni M, Gopalakrishnan R, Vaishya R, Prabu P. D-dimer level is a useful predictor for mortality in patients with COVID-19: Analysis of 483 cases. Diabetes Metab Syndr. Nov-Dec 2020;14(6):2245-2249.

10. Vidali S, Morosetti D, Cossu E, et al. D-dimer as an indicator of prognosis in SARS-CoV-2 infection: a systematic review. ERJ Open Res. Apr 2020;6(2).

11. Rizo-Tellez SA, Mendez-Garcia LA, Flores-Rebollo C, et al. The Neutrophil-to-Monocyte Ratio and Lymphocyte-to-Neutrophil Ratio at Admission Predict In-Hospital Mortality in Mexican Patients with Severe SARS-CoV-2 Infection (Covid-19). Microorganisms. Oct 10 2020;8(10).

12. Chen W, Zheng KI, Liu S, Yan Z, Xu C, Qiao Z. Plasma CRP level is positively associated with the severity of COVID-19. Ann Clin Microbiol Antimicrob. May 15 2020;19(1):18.

13. $\mathrm{XuJB}, \mathrm{Xu} \mathrm{C}$, Zhang RB, et al. Associations of procalcitonin, C-reaction protein and neutrophilto-lymphocyte ratio with mortality in hospitalized COVID-19 patients in China. Sci Rep. Sep 14 2020;10(1):15058.

14. Peng J, Qi D, Yuan G, et al. Diagnostic value of peripheral hematologic markers for coronavirus disease 2019 (COVID-19): A multicenter, cross-sectional study. J Clin Lab Anal. Oct 2020;34(10):e23475.

15. Dong $X$, Sun L, Li Y. Prognostic value of lactate dehydrogenase for in-hospital mortality in severe and critically ill patients with COVID-19. Int J Med Sci. 2020;17(14):2225-2231.

16. Li C, Ye J, Chen Q, et al. Elevated Lactate Dehydrogenase (LDH) level as an independent risk factor for the severity and mortality of COVID-19. www.aging-us.com. 2020;12(15).

17. Tural Onur S, Altin S, Sokucu SN, et al. Could ferritin level be an indicator of COVID-19 disease mortality? J Med Virol. Mar 2021;93(3):1672-1677. 
medRxiv preprint doi: https://doi.org/10.1101/2021.12.30.21266217; this version posted January 1, 2022. The copyright holder for this preprint (which was not certified by peer review) is the author/funder, who has granted medRxiv a license to display the preprint in It is made available under a CC-BY-NC-ND 4.0 International license .

18. Shang L, Shao M, Guo Q, et al. Diabetes Mellitus is Associated with Severe Infection and Mortality in Patients with COVID-19: A Systematic Review and Meta-analysis. Arch Med Res. Oct 2020;51(7):700-709.

19. Kaminska $H$, Szarpak L, Kosior D, et al. Impact of diabetes mellitus on in-hospital mortality in adult patients with COVID-19: a systematic review and meta-analysis. Acta Diabetol. Aug 2021;58(8):1101-1110.

20. Huang I, Lim MA, Pranata R. Diabetes mellitus is associated with increased mortality and severity of disease in COVID-19 pneumonia - A systematic review, meta-analysis, and metaregression. Diabetes Metab Syndr. Jul - Aug 2020;14(4):395-403.

21. Magdy Beshbishy A, Oti VB, Hussein DE, et al. Factors Behind the Higher COVID-19 Risk in Diabetes: A Critical Review. Front Public Health. 2021;9:591982.

22. Corona G, Pizzocaro A, Vena W, et al. Diabetes is most important cause for mortality in COVID19 hospitalized patients: Systematic review and meta-analysis. Rev Endocr Metab Disord. Jun 2021;22(2):275-296.

23. Miller LE, Bhattacharyya R, Miller AL. Diabetes mellitus increases the risk of hospital mortality in patients with Covid-19: Systematic review with meta-analysis. Medicine (Baltimore). Oct 2 2020;99(40):e22439.

24. Deng $F$, Zhang $L$, Lyu $L$, et al. Increased levels of ferritin on admission predicts intensive care unit mortality in patients with COVID-19. Med Clin (Engl Ed). Apr 9 2021;156(7):324-331.

25. Elemam NM, Hannawi H, Salmi IA, Naeem KB, Alokaily F, Hannawi S. Diabetes mellitus as a comorbidity in COVID-19 infection in the United Arab Emirates. Saudi Med J. Feb 2021;42(2):170-180.

26. Yan Y, Yang Y, Wang F, et al. Clinical characteristics and outcomes of patients with severe covid-19 with diabetes. BMJ Open Diabetes Res Care. Apr 2020;8(1).

27. Schlesinger $S$, Neuenschwander $M$, Lang $A$, et al. Risk phenotypes of diabetes and association with COVID-19 severity and death: a living systematic review and meta-analysis. Diabetologia. Jul 2021;64(7):1480-1491.

28. Carrasco-Sanchez FJ, Lopez-Carmona MD, Martinez-Marcos FJ, et al. Admission hyperglycaemia as a predictor of mortality in patients hospitalized with COVID-19 regardless of diabetes status: data from the Spanish SEMI-COVID-19 Registry. Ann Med. Dec 2021;53(1):103-116.

29. Yang $Y$, Chen XFD, Chen $Y$, Xie $H$, Xie C, Ying L. The influence of hypoglycemia and hyperglycemia on the adverse outcome of COVID-19 combined with diabetes mellitus: A protocol for systematic review and meta-analysis. Medicine (Baltimore). Oct 30 2020;99(44):e22587.

30. Wang $\mathrm{S}, \mathrm{Ma} \mathrm{P}$, Zhang $\mathrm{S}$, et al. Fasting blood glucose at admission is an independent predictor for 28-day mortality in patients with COVID-19 without previous diagnosis of diabetes: a multicentre retrospective study. Diabetologia. Oct 2020;63(10):2102-2111.

31. Ceriello A, Standl E, Catrinoiu D, et al. Issues for the management of people with diabetes and COVID-19 in ICU. Cardiovasc Diabetol. Jul 20 2020;19(1):114. 
medRxiv preprint doi: https://doi.org/10.1101/2021.12.30.21266217; this version posted January 1, 2022. The copyright holder for this preprint (which was not certified by peer review) is the author/funder, who has granted medRxiv a license to display the preprint in It is made available under a CC-BY-NC-ND 4.0 International license .

Supp 1. The Association between Diabetes and Intensive care treatment in COVID-19 patients

\begin{tabular}{|c|c|c|c|c|}
\hline \multirow[t]{2}{*}{ Variable } & \multicolumn{2}{|c|}{ Intensive care treatment-n (\%) } & \multirow{2}{*}{$\begin{array}{l}\text { RR crude } \\
(95 \% \mathrm{Cl})\end{array}$} & \multirow{2}{*}{$\begin{array}{l}\text { OR adjusted } \\
(95 \% \mathrm{Cl})\end{array}$} \\
\hline & $\begin{array}{c}\text { Yes } \\
N=55 \\
(20.83 \%)\end{array}$ & $\begin{array}{c}\text { No } \\
N=209 \\
(79.17 \%)\end{array}$ & & \\
\hline \multicolumn{5}{|l|}{ Diabetes } \\
\hline Yes & $21(38.18 \%)$ & $21(10.055)$ & $3.27(2.12-5.03) * *$ & $2.57(1.08-6.12)^{*}$ \\
\hline No & $34(61.82 \%)$ & $188(89.95 \%)$ & 1.00 & 1.00 \\
\hline \multicolumn{5}{|l|}{ Age, years } \\
\hline$\geq 60$ years & 26 (47.27\%) & 34 (16.27\%) & $3.05(1.96-4.75) * *$ & $1.70(0.76-3.80)$ \\
\hline$<60$ years & 29 (52.73\%) & $175(83.73 \%)$ & 1.00 & 1.00 \\
\hline \multicolumn{5}{|l|}{ Sex } \\
\hline Male & 27 (49.09\%) & 72 (34.45\%) & $1.61(1.00-2.56) *$ & \\
\hline Female & $28(50.91 \%)$ & 137 (65.55\%) & 1.00 & \\
\hline \multicolumn{5}{|l|}{ Comorbidity } \\
\hline$\geq 2$ comorbids & $19(34.55 \%)$ & $15(7.18 \%)$ & $5.24(2.59-10.62) * *$ & $7.27(2.48-21.26)^{* *}$ \\
\hline$\overline{1}$ comorbid & $23(41.82 \%)$ & $85(40.67 \%)$ & $2.00(1.01-3.95)^{*}$ & $2.11(0.88-5.09)$ \\
\hline $\begin{array}{l}\text { Without } \\
\text { comorbid }\end{array}$ & $13(23.64 \%)$ & 109 (52.15\%) & 1.00 & 1.00 \\
\hline \multicolumn{5}{|l|}{$\mathrm{RBG}, \mathrm{mg} / \mathrm{dL}$} \\
\hline$\geq 180 \mathrm{mg} / \mathrm{dL}$ & $15(27.27 \%)$ & 17 (8.13\%) & $2.72(1.71-4.33) * *$ & \\
\hline$<180 \mathrm{mg} / \mathrm{dL}$ & 40 (72.73\%) & 192 (91.87\%) & 1.00 & \\
\hline \multicolumn{5}{|l|}{$\mathrm{CRP}, \mathrm{mg} / \mathrm{dL}$} \\
\hline$\geq 2,587 \mathrm{mg} / \mathrm{dL}$ & 43 (78.18\%) & $86(41.15 \%)$ & $3.75(2.07-6.78) * *$ & \\
\hline$<2,587 \mathrm{mg} / \mathrm{dL}$ & $12(21.82 \%)$ & $123(58.85 \%)$ & 1.00 & \\
\hline \multicolumn{5}{|l|}{ Ferritin, $\mathrm{ng} / \mathrm{mL}$} \\
\hline$\geq 163,5 \mathrm{ng} / \mathrm{mL}$ & 52 (94.55\%) & 130 (62.20\%) & $7.81(2.51-24.28) * *$ & $7.45(1.78-31.24)^{* *}$ \\
\hline$<163,5 \mathrm{ng} / \mathrm{mL}$ & $3(5.45 \%)$ & 79 (37.80\%) & 1.00 & 1.00 \\
\hline \multicolumn{5}{|l|}{ D-dimer, ng/mL } \\
\hline$\geq 565 \mathrm{ng} / \mathrm{mL}$ & 50 (90.91\%) & $113(54.07 \%)$ & $6.20(2.56-15.02) * *$ & \\
\hline$<565 \mathrm{ng} / \mathrm{mL}$ & $5(9.09 \%)$ & 96 (45.93\%) & 1.00 & \\
\hline \multicolumn{5}{|l|}{ LDH, u/L } \\
\hline$\geq 277 \mathrm{u} / \mathrm{L}$ & 53 (96.36\%) & 179 (85.65\%) & $3.66(0.94-14.28)$ * & \\
\hline$<277 \mathrm{u} / \mathrm{L}$ & $2(3.64 \%)$ & 30 (14.35\%) & 1.00 & \\
\hline \multicolumn{5}{|l|}{ NLR } \\
\hline$\geq 5,870$ & 39 (70.91\%) & 41 (19.62\%) & $5.61(3.34-9.42) * *$ & $8.75(4.03-19.01)^{* *}$ \\
\hline$<5,870$ & 16 (29.09\%) & $168(80.38 \%)$ & 1.00 & 1.00 \\
\hline \multicolumn{5}{|l|}{ MLR } \\
\hline$\geq 0,300$ & 46 (83.64\%) & 109 (52.15\%) & $3.59(1.84-7.03) * *$ & \\
\hline$<0,300$ & $9(16.36 \%)$ & $100(47.85 \%)$ & 1.00 & \\
\hline
\end{tabular}

Supp 2. The Association between Diabetes and mortality in COVID-19 patients

\begin{tabular}{lccll}
\hline Variable & \multicolumn{2}{c}{ Mortality- $\mathrm{n}(\%)$} & $\begin{array}{l}R R \text { crude } \\
(95 \% \mathrm{Cl})\end{array}$ & $\begin{array}{l}\text { OR adjusted } \\
(95 \% \mathrm{Cl})\end{array}$ \\
\cline { 2 - 5 } & $\begin{array}{c}\text { Yes } \\
\mathrm{N}=140\end{array}$ & $\mathrm{~N}=366$ & & \\
& $(27.67 \%)$ & $(72.33 \%)$ & & \\
\hline $\begin{array}{c}\text { Diabetes } \\
\text { Yes }\end{array}$ & $\mathbf{6 5 ( 4 5 , 1 4 )}$ & $\mathbf{7 9 ( 5 4 , 8 6 )}$ & $\mathbf{2 . 1 8 ( 1 . 6 6 - 2 . 8 6 ) * *}$ & $\mathbf{2 , 5 0 ( 1 . 6 1 - 3 , 8 9 ) * *}$ \\
No & $\mathbf{7 5 ( 2 0 , 7 2 )}$ & $\mathbf{2 8 7}(\mathbf{7 9 , 2 8})$ & $\mathbf{1 , 0 0}$ & $\mathbf{1 , 0 0}$ \\
Age, years & & & & \\
\hline
\end{tabular}


medRxiv preprint doi: https://doi.org/10.1101/2021.12.30.21266217; this version posted January 1, 2022. The copyright holder for this preprint (which was not certified by peer review) is the author/funder, who has granted medRxiv a license to display the preprint in It is made available under a CC-BY-NC-ND 4.0 International license .

\begin{tabular}{|c|c|c|c|c|}
\hline$\geq 60$ years & $54(37,76)$ & $89(62,24)$ & $1.59(1.21-2.19) * *$ & $1,68(1,08-2,63)^{*}$ \\
\hline$<60$ years & $86(23,69)$ & $277(76,31)$ & 1,00 & 1,00 \\
\hline \multicolumn{5}{|l|}{ Sex } \\
\hline Male & $71(32,13)$ & $150(67,87)$ & $1,32(0.99-1.74)$ & \\
\hline Female & $69(24,21)$ & $216(75,79)$ & 1,00 & \\
\hline \multicolumn{5}{|l|}{ Comorbidity } \\
\hline$\geq 2$ comorbid & $44(42,31)$ & $60(57,69)$ & $3.23(2.03-5.14) * *$ & $1,76(1,04-2,97) *$ \\
\hline$\overline{1}$ comorbid & $41(24,70)$ & $125(75,30)$ & $1.95(1.23-3.10)$ & $0,79(0,48-1,30)$ \\
\hline $\begin{array}{l}\text { Without } \\
\text { comorbid }\end{array}$ & $55(23,31)$ & $181(76,69)$ & 1,00 & 1,00 \\
\hline \multicolumn{5}{|l|}{$\mathrm{RBG}, \mathrm{mg} / \mathrm{dL}$} \\
\hline$\geq 180 \mathrm{mg} / \mathrm{dL}$ & $38(42,70)$ & $51(57,30)$ & $1.96(1.48-2.59) * *$ & \\
\hline$<180 \mathrm{mg} / \mathrm{dL}$ & $102(24,46)$ & $315(75,54)$ & 1,00 & \\
\hline \multicolumn{5}{|l|}{$\mathrm{CRP}, \mathrm{mg} / \mathrm{dL}$} \\
\hline$\geq 5,213 \mathrm{mg} / \mathrm{dL}$ & $87(37,34)$ & $146(62,66)$ & $3.76(2.61-5.40) * *$ & $1,90(1,21-2,99) * *$ \\
\hline$<5,213 \mathrm{mg} / \mathrm{dL}$ & $53(19,41)$ & $220(80,59)$ & 1,00 & 1,00 \\
\hline \multicolumn{5}{|l|}{ Ferritin, ng/mL } \\
\hline$\geq 304,3 \mathrm{ng} / \mathrm{mL}$ & $109(31,50)$ & $237(68,50)$ & $1,91(1,20-3,18) * *$ & \\
\hline$<304,3 \mathrm{ng} / \mathrm{mL}$ & $31(19,38)$ & $129(80,62)$ & 1,00 & \\
\hline \multicolumn{5}{|l|}{ d-dimer, $\mathrm{ng} / \mathrm{mL}$} \\
\hline$\geq 2.010 \mathrm{ng} / \mathrm{mL}$ & $79(37,26)$ & $133(62,74)$ & $3.89(2.27-6,65) * *$ & $1,65(1,05-2,58) *$ \\
\hline$<2.010 \mathrm{ng} / \mathrm{mL}$ & $61(20,75)$ & $233(79,25)$ & 1,00 & 1,00 \\
\hline \multicolumn{5}{|l|}{$\mathrm{LDH}, \mathrm{u} / \mathrm{L}$} \\
\hline$\geq 353,5 \mathrm{u} / \mathrm{L}$ & $122(31,12)$ & $270(68,88)$ & $3.06(2.27-4.12) * *$ & \\
\hline$<353,5 \mathrm{u} / \mathrm{L}$ & $18(15,79)$ & $96(84,21)$ & 1,00 & \\
\hline \multicolumn{5}{|l|}{ NLR } \\
\hline$\geq 8,085$ & $31(26,27)$ & $87(73,73)$ & $3,27(2.46-4.36) * *$ & \\
\hline$<8,085$ & $109(28,09)$ & $279(71,91)$ & 1,00 & \\
\hline \multicolumn{5}{|l|}{ MLR } \\
\hline$\geq 0,364$ & $90(28,66)$ & $224(71,34)$ & $2,78(1,93-3.99) * *$ & \\
\hline$<0,364$ & $50(26,04)$ & $142(73,96)$ & 1,00 & \\
\hline
\end{tabular}

